\title{
КОНЦЕНТРИРОВАНИЕ ИОНОВ СУРЬМЫ ЛЕГКОПЛАВКИМ ЭКСТРАГЕНТОМ ИЗ КИСЛЫХ ХЛОРИДНЫХ РАСТВОРОВ
}

\author{
Зюськина В.А., Темерев С.В. \\ ФГБОУ ВПО Алтайский государственный университет, Барнаул, Россия \\ zuskina_elena@mail.ru
}

DOI: 10.26902/ASFE-11_156

Подготовка образцов к анализу на 40-60 \%определяет результат инструментального метода. Как правило, инструментальный анализ $\mathrm{As}, \mathrm{Sb}, \mathrm{Sn}, \mathrm{Bi}, \mathrm{Se}, \mathrm{Te}$ и других летучих элементов в экосистемах требует предварительного концентрирования. Элементы IV - VI групп отличает способность образовывать газообразные гидриды, которые можно отделить от сложной матрицы анализируемого образца в виде гидридов в практическом анализе ртутеподобных элементов [1].

Настоящее сообщение посвящено аналитическому применению легкоплавкого расплава - сульфасалицилатагексилдиантипирилметания для концентрирования ионных форм сурьмы из кислых хлоридных растворов. Данный расплав является новым перспективным легкоплавким экстрагентом, плавится при температуре ниже температуры кипения воды $(77 \pm 1){ }^{\circ} \mathrm{C}$ и образует плотнуюгидрофобную $(2,28 \pm 0,02) \quad \Gamma / \mathrm{cm}^{3}$ ионную жидкость. Расплав обеспечивает простоту количественного концентрирования ионов $\mathrm{Sb}$ (III) из кислого водного раствора, удобство выполнения подготовки концентрата и эффективность извлечения ионов сурьмы с окончанием процедуры анализа инструментальным методом (рентгенофлуоресцентным, беспламенным абсорбционным, вольтамперометрическим и др.).

Серию модельных систем готовили в термостойких градуированных пробирках. Вносили химические реагенты: гексилдиантипирилметан и сульфосалициловую кислоту; нагревали до образования жидкости. В пробиркис остывшим расплавом вносили различные концентрации $\mathrm{Sb}(\mathrm{III})$ из рабочего раствора, и воды до общего объема10 мл. Для экстракции пробирки с внесенными растворами помещали на водяную баню и грели до температуры 80$85{ }^{\circ} \mathrm{C}$ (органическая фаза вновь становилась жидкой), после чего пробирки тщательно встряхивали в течение 2-3 минут и оставляли остывать. Когда органическая фаза полностью застывала, отделяли ее от водной фазы. Для растворения твердой фазы добавляли этиловый спирт (1,00 мл). Водную фазу анализировали 2-мя независимыми методами: ААС с электротермической атомизацией и оригинальным электрохимическим способом (BA). По результатам двух независимых методов отмечено, что они удовлетворяют $\mathrm{t}$-критерию (погрешности статистически не значимы).

Электрохимический способ определения сурьмы не основан на высоких температурах, заимствует технологию гидридного метода - в качестве восстановителя элемента применяется щелочной раствор борогидрида натрия. В качестве модельных систем - выбраны кислые водные растворы, фоновых систем - растворы хлороводородной кислоты (ХЧ) с добавками сурьмы (III). Вольтамперометрический способ определения ионов сурьмы выполнялся с помощью графитового электрода (анализатора Экотест ВА Москва), входящего в комплект анализатора. Рабочий электрод не содержит токсичной ртутной пленки и безопасен в работе, может храниться в сухом виде, более удобен в эксплуатации, обеспечивает удовлетворительный коэффициент чувствительности 8,1 [мкА/мкгSb]. Установлены оптимальные условия регистрации аналитического сигнала.

\section{Сиисок литературы}

1. Антропова Д. Г.,Темерев С. В. Определение мышьяка и селена в водных растворах после концентрирования легкоплавким расплавом / Д. Г. Антропова, С. В. Темерев // Ползуновскийвестник. - 2016. - № 4, т. 2. - С. 149 154. 